\title{
ARTICLES
}

\section{Belgium and Democratic Constitution-Making: Prospects for the Future?}

\author{
Ronald Van Crombrugge
}

\section{Introduction}

What role - if any -should citizens play in the making or amending of constitutions? This question is the subject of ongoing debate. Although no true consensus has of yet emerged, there seems to be a genuine trend towards more democratic forms of constitution-making. ${ }^{1}$ More and more it is argued that 'a democratic constitution is no longer simply one that establishes democratic governance. It is also a constitution that is made in a democratic process.' ${ }^{2}$ An increased level of public participation is seen by several authors as one of the important common features of modern constitution-making. ${ }^{3}$

The reasons why democratic constitution-making is now so actively endorsed are numerous. First of all, democratic constitution-making is seen as instrumental to achieving other goals. It is argued that popular participation in the constitutionmaking process is essential to ensure that a constitution is effective and that the population endorses the principles it enshrines - in other words, to ensure that it is seen as legitimate by the citizens who are subject to it. ${ }^{4}$ For this reason, democratic constitution-making is also said to assist in a smooth transition from con-

1 Cheryl Saunders, 'Constitution Making in the 21st Century,' International Review of Law 4 (2012): 2; Mark Tushnet, 'New Institutional Mechanisms for Making Constitutional Law,' Harvard Public Law Working Paper No. 15-08 (April 2, 2015): 7, accessed September 12, 2016, http://papers.ssrn. com/sol3/papers.cfm?abstract_id=2589178\#\#; Zachary Elkins, Tom Ginsburg and Justin Blount, 'The Citizen as Founder: Public Participation in Constitutional Approval,' Temple Law Review 81 (2008): 361.

2 Vivien Hart, 'Democratic Constitution Making,' USIP Special Report 107 (2003): 4, accessed September 21, 2015,http://www.usip.org.

3 Saunders, 'Constitution Making in the 21st Century,' 9; Christopher Zurn, 'Democratic Constitutional Change: Assessing Institutional Possibilities,' SSRN Working Paper (2015), accessed October 10, 2015, http://papers.ssrn.com/sol3/papers.cfm?abstract_id=2630363; Claude Klein and Andràs Sajó, 'Constitution-Making: Process and Substance,' in The Oxford Handbook of Comparative Constitutional Law (Oxford: Oxford University Press, 2012), 434 and 436; Tushnet, 'New Institutional Mechanisms,' 7.

4 Saunders, 'Constitution Making in the 21st Century,' 1-10; Jason Gluck and Brendan Ballou, 'New Technologies in Constitution Making,' USIP Special Report 343 (2013): 2, accessed October 12, 2015, htpp://www.usip.org; Hélène Landemore, 'Inclusive Constitution-Making: The Icelandic Experiment,' Journal of Political Philosophy 23 (2014): 24; Patricia Popelier, 'De truc met artikel 195: een lapje voor het bloeden met de zegen van Venetië,' CDPK (2012): 423; Hart, 'Democratic Constitution Making,' 4; Zachary Elkins, Tom Ginsburg and James Melton, The Endurance of National Constitutions (Cambridge: Cambridge University Press, 2009), 78. 
flict or autocracy to democracy. ${ }^{5}$ Lastly, it is argued that the process of constitution-making has an effect on the actual content of the constitution itself. A more democratic process of constitution-making would result in a constitution that is itself more democratic, recognizing more fundamental rights for its citizens as well as providing more avenues for citizens to influence public policy. ${ }^{6}$

Even though the empirical evidence for these claims is still limited - but nonetheless cautiously positive ${ }^{7}$ - it can still be argued that the active participation of citizens in the making of the constitution is of intrinsic value to a democratic society. Of course, such a normative argument in favour of democratic constitutionmaking already presupposes a certain understanding of democracy itself. While more 'participatory' theories of democracy ${ }^{8}$ may be committed to democratic constitution-making, other theories do not necessarily share this commitment. ${ }^{9}$ This being so, it is important to note that this paper looks at the constitution-making process from the perspective of participatory democracy - understood in its broadest sense - and that this choice is of course not normatively neutral.

In sharp contrast with the norms of participatory democracy stands the Belgian experience with constitution-making. The unitary Belgian state has over time been gradually transformed into a federation through a number of 'state reforms,' which were the result of political bargains struck between party leaders behind closed doors. Precisely because of this contrast, the Belgian case offers a good

5 Kirsti Samuels, Constitution Building Processes and Democratization: A discussion of Twelve Case Studies (Geneva: IDEA, 2006); Kirsti Samuels, 'Post-Conflict Peace-Building and ConstitutionMaking,' Chicago Journal of International Law 6 (2006): 667.

6 Samuels, 'Post-Conflict Peace-Building and Constitution-Making,' 668; Zachary Elkins, Tom Ginsburg and Justin Blount, 'The Citizen as Founder : Public Participation in Constitutional Approval,' Temple Law Review 81 (2008): 381.

7 Tom Ginsburg, Zachary Elkins and Justin Blount, 'Does the Process of Constitution-Making Matter?' Annual Review of Law and Social Science 5 (2009): 219.

8 While the term 'participatory democracy' is often used to refer to a specific model of democracy, for pragmatic reasons I employ the term here in a broader sense to refer to a larger set of democratic theories that emphasize the importance of citizen participation in public decision-making, not just through regular voting at elections, but also through discussion and debate. Important examples are participatory democracy (in the strict sense), civic republicanism, deliberative democracy, discursive democracy, ... See Banks for a similar approach of grouping these different theories together for the purpose of discussing democratic constitution-making: Angela M. Banks, 'Expanding Participation in Constitution-Making: Challenges and Opportunities,' William and Mary Law Review 49 (2008): 1046.

9 As an example, reference could be made here to Lijphart's theory of 'consociational democracy' which relies on agreement between the leaders of each bloc to share government. In this model, the making of the constitution does not rely on the involvement of individual citizens. Rather, constitution-making on the basis of elite-bargaining is seen as essential for success, since it is this pact between elites that generates the institutional foundations for consociational governance, namely: grand coalitions, segmental autonomy, proportionality, and minority veto (Arend Lijphart, Democracy in Plural Societies: A Comparative Exploration [New Haven, CT: Yale University Press, 1977]. For a critique of this model of government from the 'participatory' perspective of deliberative democracy, see John S. Dryzek, 'Deliberative Democracy in Divided Societies: Alternatives to Agonism and Analgesia,' Political Theory 33 [2005]: 218-42). 
opportunity to explore alternative, more democratic, means of constitution-making.

The paper starts by discussing the current procedure for constitutional amendment, which is laid out in article 195 of the Belgian constitution. ${ }^{10}$ While the objectives this procedure originally intended to fulfil can still be considered useful today, there seems to be widespread consensus that the procedure has become deficient and is no longer able to fulfil these goals. The paper does not aim to propose a completely new procedure, but simply seeks to explore a general idea, namely whether more participation by citizens during the constitution-making process could help to achieve the objectives that lie at the basis of the procedure of article 195. This idea will then be fleshed out by evaluating and comparing two concrete examples of more democratic constitution-making. Namely the constitution-making process that was set up in Iceland after the 2008 financial crisis and the process that led to the new, post-apartheid constitution in South Africa in 1996. The most important reason for choosing precisely these two examples is that the extent to which citizens were able to participate differed greatly between them. Whereas Iceland strived towards an almost exclusively citizen-led drafting process, the South African process was much more modest in its participatory objectives. This allows for a more critical approach to the radically participatory process in Iceland by also asking how and when political elites played a positive role in the South African experience, and in contrast, how and when more direct forms of citizen participation could have complemented the South African process. After having compared and evaluated both processes, the paper concludes with some general reflections on the lessons that can be drawn from these two experiences and what this could mean for the prospect of democratic constitution-making in Belgium.

\section{Constitutional reform in Belgium}

\subsection{Article 195 of the Belgian constitution and its objectives}

As mentioned before, article 195 of the Belgian constitution sets out the procedure for its amendment. This procedure consists of three distinct phases, namely the adoption of a 'declaration of revision' by the existing legislature, the dissolution of parliament followed by elections, and the actual revision of the constitution by the newly formed parliament. In the first phase, each branch of the legislature has to adopt (by simple majority) a declaration of revision, containing all the articles deemed opportune for revision. Only those articles that appear identi-

10 The field of application of this article has been interpreted broadly, so that it also applies when drafting an entirely new constitution. For a more general discussion of this approach to constitution-making, see 'Constitution-Making "By the Rules,"' in Klein and Sajó, 'Constitution-Making: Process and Substance,' 433. 
cally in each of the three declarations will eventually be able to be revised. ${ }^{11}$ The adoption of the three declarations automatically triggers the second phase of the procedure, namely the dissolution of parliament and - consequently - the holding of elections. ${ }^{12}$ Once the newly elected parliament is convened, the third and final phase of the procedure can take place: the actual revision of the constitution. In order to amend the constitution, a double two-thirds majority is required in each of the parliamentary chambers: two-thirds of the members have to be present, and two-thirds of the votes have to be in favour of the revision. ${ }^{13}$ While the newly elected parliament is bound by the declarations of revision with regard to the articles that can be amended, it is not bound by the substantive content of the proposals included in the declarations. ${ }^{14}$

This procedure was intended to fulfil two different functions. Firstly, to ensure the stability of the constitution (stabilizing function) and secondly, to legitimize constitutional revisions (democratic function). ${ }^{15}$ Stability was to be ensured in several ways. First of all, the heightened majority requirement ensures that the constitution can only be amended if a broad consensus exists. ${ }^{16}$ The dissolution of parliament supplements this and adds a temporal element to the required consensus, by requiring that a consensus lasts through two legislatures. ${ }^{17}$ Additionally, the spreading of the procedure over two different legislatures ensures that no random majority - however large it may be - can adapt the constitution with the sole purpose of maintaining power or entrenching its policies. ${ }^{18}$ The democratic function was to be fulfilled by the holding of elections. ${ }^{19}$ This would allow the electorate to make its voice heard on the issue of constitutional reform. The newly elected parliament would then take the opinion of the voters into account.

11 Emmanuel Vandenbossche, 'De herziening van artikel 195 van de Grondwet. Een noodzaak tot demystificatie,' in Scharnier- of sleutelelementen in het grondwettelijk recht, ed. Alexander De Becker and Emmanuel Vandenbossche (Brugge: die Keure, 2011), 61; Johan Vande Lanotte and Geert Goedertier, Handboek Belgisch publiekrecht (Brugge: die Keure, 2014), nr. 157; Marc Uyttendaele, Trente leçons de droit constitutionnel (Brussels: Bruylant, 2011), 91.

12 André Alen and Koen Muylle, Handboek van het Belgisch staatsrecht (Antwerpen: Kluwer, 2011), 230; Bernard Blero, 'L'article 195 de la constitution, une pierre angulaire à retailler?,' in Scharnier- of sleutelelementen, ed. De Becker and Vandenbossche, 9.

13 Alen and Muylle, Handboek, 232.

14 Alen and Muylle, Handboek, 233; Vande Lanotte and Goedertier, Handboek, nr. 221.

15 Blero, 'L'article 195 de la constitution,' 12.

16 Blero, 'L'article 195 de la constitution,' 15.

17 Blero, 'L'article 195 de la constitution,' 15; Popelier, 'De truc met artikel 195,' 426.

18 Karel Rimanque, De Grondwet toegelicht, gewikt en gewogen (Antwerpen: Intersentia, 2005), 421; Popelier, 'De truc met artikel 195,' 426.

19 Alen and Muylle, Handboek, 231. 


\subsection{Deficiencies of the current procedure}

Since around 1965, Belgium has been engaged in a continuous process of constitutional reform since each reform carries within it the seeds for the next. ${ }^{20}$ As a result, a consistent practice has developed of adopting a declaration of revision at the end of each legislature. What was originally supposed to be an exceptional event, has now become the normal means of dissolving parliament. ${ }^{21}$ Because of this, it has become difficult for the procedure of article 195 to fulfil its stabilizing and democratic functions.

While the need for consensus amongst two successive legislatures still provides protection against abuse of the constitution, ${ }^{22}$ it could be argued that it is not the right instrument to achieve this result because it makes it impossible for elections to effectively fulfil their democratic function. While the newly elected parliament is supposed to take the election results into account, the possibilities to actually do so are limited, because it can only adapt those provisions that are included in the declarations of revision, even when there is a very broad societal consensus that it is opportune to adapt other articles as well.

At the same time, it has also become clear that the holding of elections is simply not an effective means to organize the participation of citizens. While elections should in principle offer a powerful democratic mandate to the drafters of the constitution, this is often not the case in Belgium. Because the declaration of revision is generally adopted at the end of every single legislature, elections are most often dominated by questions on normal policy while the issue of constitutional reform gets pushed to the background. ${ }^{23}$ Still, in exceptional circumstances - such as during constitutional crises when the issue of state reform is the main issue of the election campaign - elections still provide an important democratic check during the amendment process. ${ }^{24}$ However, even then elections are by themselves insufficient from a democratic point of view because the possibilities for voters to actually influence the content of the new or revised constitution are extremely limited. First of all, since constitutional reforms in Belgium typically require the consent of more than six political parties, it becomes impossible to derive any sort of 'general will' from these different election results. ${ }^{25}$ Moreover, because the negotiations are typically led by a select group of high-ranking party officials and take place behind closed doors, public scrutiny of the constitution-

20 Blero, 'L'article 195 de la constitution,' 16; Xavier Delgrange and Huges Dumont, 'Le rhytme des révisions constitutionnelles et l'hypothèse de l'accélération du temps juridique,' in L'accélaration du temps juridique, ed. Philippe Gérard, François Ost and Michel van de Kerckhove (Brussels: F.U.S.L., 2000), 432.

21 Blero, 'L'article 195 de la Constitution,' 23; Uyttendaele, Trente leçons, 100.

22 Popelier, 'De truc met artikel 195,' 426.

23 Blero, 'L'article 195 de la constitution,' 24.

24 Alen and Muylle, Handboek, 231; André Alen, X. in La procédure de révision de la constitution, ed. Francis Delpérée (Brussels: Bruylant, 2003), 45-48, 165-68.

25 Alen and Muylle, Handboek, 24; Marc Uyttendaele, 'L'article 195 de la constittution - le diagnostic ou comment aménager au mieux le potlach,' in La procédure de révision de la constitution (Brussels: Bruylant, 2003), 39. 
making process through the informal public sphere is made impossible, while the involvement of parliament is reduced to rubberstamping the resulting compromise ex post facto.

\section{Democratic constitution-making as solution?}

Because of these deficiencies, there seems to exist a broad consensus that article 195 should be amended. ${ }^{26}$ At the same time, however, the concerns that lie at the basis of the original procedure remain valid today, and should therefore preferably be reflected in the new procedure as well. This article seeks to contribute to this debate by asking how a more democratic process of constitutional revision could not only contribute to the fulfilment of the democratic function, but also to the fulfilment of the stabilizing function.

It has already been noted that Belgium is engaged in a continuous process of constitutional reform. How should one look at the objective of ensuring the stability of the constitution in such a context, when practice has shown that the dissolution requirement - which was precisely intended to safeguard stability - can frustrate changes that enjoy a broad consensus and even cause a constitutional crisis? An answer can possibly be found in what authors have termed 'democratic constitutionalism. ${ }^{27}$ While this theory still rests on a clear distinction between the constitution and ordinary legislation through some form of (moderate) entrenchment of the former, ${ }^{28}$ the focus is placed less on the longevity of the constitution and more on the possibilities that exist for citizens to participate in the process of constitution-making, so that they can see themselves not only as subject to, but also as 'co-author' of the constitutional text. ${ }^{29}$ Hutchinson and Colón-Rios for example have argued that:

'From a democratist standpoint, the merit of a constitution is to be found not so much in its longevity and its force towards stability, but in its capacity for both democratic participation and constitutional transformation. (...) [T]here must be adequate mechanisms and processes in place to maximize these opportunities. ${ }^{30}$ Bruylant, 2003).

27 See Zurn, 'Democratic Constitutional Change,' 5; Allan Hutchinson and Joël I. Colón-Rios, 'Democracy and Constitutional Change,' Theoria: A Journal of Social and Political Theory (2011): 43-62; James Tully, Introduction to Multinational Democracies, ed. Alain-G. Gagnon and James Tully (Cambridge: Cambridge University Press, 2001), 24; Joel I. Colón-Rios, Weak Constitutionalism: Democratic Legitimacy and the Question of Constituent Power (London: Routledge, 2013), 3.

29 Zurn, 'Democratic Constitutional Change,' 11.

30 Hutchinson and Colón-Rios. 'Democracy and Constitutional Change,' 57. 
Unlike traditional constitutionalism, the stability of the constitutional order is no longer defined by the endurance of the constitution. ${ }^{31}$ According to democratic constitutionalists, a stable constitution is not so much a constitution that is able to prevent change, but a constitution that has the necessary mechanisms in place that enable it to retain its legitimacy and the commitment for its respect throughout these changes. This is especially important in divided societies or multinational states such as Belgium. Because these states cannot be based on a 'thick' notion of national identity, it is necessary 'that citizens share a common civic allegiance to the rules and procedures by which democratic decisions are arrived at, rather than to some thicker, substantive account of civic identity.' 32 The inclusiveness and openness of the constitution-making process - including the degree to which citizens were able to participate in that process - are some of the most important factors for the constitution's legitimacy, and will therefore be (at least partially) determinative for its effectivity, understood as the commitment for its respect. $^{33}$

Tully as well has argued that opportunities for popular participation and deliberation during moments of constitution-making are an important basis of stability in multinational societies, because they act as a process of citinization. ${ }^{34} \mathrm{He}$ argues that:

'[Individuals and minorities], and the members of the larger society, become citizens of the larger multinational society by participating in the processes of identity formation and discussion of the proposed identity of the multinational democracy. As a result, they develop a sense of belonging to and identification with this larger democracy in which they have a say over its constitutional forms. (...) It is sufficient that the processes of identity discussion and formation be open to the participation of those who agree and disagree. ${ }^{35}$

According to him, constitutional stability in a multinational society should therefore not be sought in some grand elite-pact, intended to last through the ages, but

31 See Elkins, Ginsburg and Melton, The Endurance of National Constitutions, who despite their general argument in favour of endurance, also stress the need for flexibility to amend or replace the constitution when it no longer fits the society for which it was drafted (35).

32 Ian O'Flynn, Deliberative Democracy and Divided Societies (Edinburgh: Edinburgh University Press, 2006), 75. Habermas calls this 'constitutional patriotism,' see Jürgen Habermas, The New Conservatism: Cultural Criticism and the Historians' Debate (Cambridge, MA: MIT Press, 1998).

33 Saunders, 'Constitution Making in the 21st Century,' 3; Popelier, 'De truc met artikel 195,' 423; Simone Chambers, 'Democracy, Popular Sovereignty, and Constitutional Legitimacy,' Constellations 11 (2004): 153; Vivien Hart, 'Democratic Constitution Making,' 4. Also see O’Flynn's argument for publicity during decision-making processes in divided societies (O'Flynn, Deliberative Democracy and Divided Societies, 119) as well as Dryzek's arguments in favour of deliberation across divisions (Dryzek, 'Deliberative Democracy in Divided Societies').

34 Tully, Introduction to Multinational Democracies, 25.

35 Tully, Introduction to Multinational Democracies, 25. 
in the reciprocal freedom of citizens to engage with each other and with the constitution in a continuous process of identity discussion and formation. ${ }^{36}$

In addition, according to Zurn, empowering citizens to assist in the drafting of the constitution helps to set the process apart from the ordinary legislative process. If the drafting of the constitution were performed by the ordinary legislature controlled by party elites, there is a risk that short-term electoral or party interests would prevail over the long-term interests of the state. ${ }^{37}$ According to him, the best way to avoid this is to entrust this task to a separate constituent assembly which is broadly representative of the different segments of society and which includes ordinary citizens. ${ }^{38}$

However, while the inclusion of ordinary citizens in the constitution-making process promises several advantages over the traditional approach of purely elite-led constitution-making, we should be careful not to expect too much from it. While some constitutionalists in the past have wrongfully tended to downplay the capacity of ordinary citizens to participate in the making or amending of constitutions, proponents of democratic constitutionalism should not make the opposite mistake of excluding political elites altogether.

First of all, one cannot escape the need for representation. ${ }^{39}$ Indeed, both in the ideal process suggested by Zurn as well as in the one proposed by Hutchinson and Colón-Rios, a crucial step is the creation of a separate constituent assembly tasked with the drafting of the constitution. ${ }^{40}$ Even though Hutchinson and Colón-Rios propose a constituent assembly consisting of ordinary citizens chosen by lot $^{41}$ and Zurn's preferred example is the election in Iceland of 25 ordinary citizens to the Constitutional Assembly (cf. infra), ${ }^{42}$ the fact remains that the logic is still very much one of representation.

36 Tully supports his claims by referring to the struggle between Quebec and Canada. According to him, it is precisely during moments that this process is closed that the Quebecois' 'sense of belonging to Canada decreases and their exclusive identification with Quebec increases' (Tully, Introduction to Multinational Democracies, 26).

37 Zurn, 'Democratic Constitutional Change,' 17. Also, see Elster's discussion of the role of group interest in constitution-making (Jon Elster, 'Forces and Mechanisms in the Constitution-Making Process,' Duke Law Journal 45 [1995]: 378).

38 Zurn, 'Democratic Constitutional Change,' 17.

39 By denying that representation has a positive role to play in democracy, one quickly ends up in a situation where a democratic politics becomes impossible in its entirety. See for example Negri, who argues that representation automatically leads to oppression and therefore argues that democracy can be found most readily in the material moment of revolution itself. According to him, the drafting of a constitution after the revolution already betrays democracy (Antonio Negri, Insurgencies: Constituent Power and the Modern State [Minneapolis: The University of Minnesota Press, 1999], 157). See also Raf Geenens et al., "The "Co-Originality" of Constituent Power and Representation,' Constellations (2015): 517.

40 Hutchinson and Colón-Rios. 'Democracy and Constitutional Change,' 53; Zurn, 'Democratic Constitutional Change,' 17.

41 Hutchinson and Colón-Rios. 'Democracy and Constitutional Change,' 56.

42 Zurn. 'Democratic Constitutional Change,' 19. 
The argument that sortition by lot is democratically superior to elections because it involves ordinary citizens instead of politicians is also not without its criticisms. Firstly, while sortition maximizes the participation of some citizens, it forces the wider public into the role of passive bystander. ${ }^{43}$ There is a fundamental difference between the right to participate and the right to having a statistical chance to participate. Secondly, while elections taken by themselves are only a minimal form of political participation and should therefore not be the sole avenue for public participation in the constitution-making process, the bonds of accountability and authorization they create between the representative and the represented, between those who are within the deliberating body and the broader public outside of it, are important from a democratic point of view and are completely lacking in the case of sortition. ${ }^{44}$

Democratic constitutionalism's emphasis on popular participation should also not result in denying the legitimate role political parties can play in the process of constitution-making. It would be a mistake to see the involvement of political parties as fundamentally at odds with popular participation. ${ }^{45}$ Of course, this is not to say that the role political parties play is always positive - indeed the picture presented before of Belgian constitution-making as bargains struck between party leaders behind closed doors shows this is clearly not the case - yet denying them any role would not improve the democratic nature of the constitution-making process. On the contrary, if the goal is to allow the entire public to participate, one should not underestimate the unique potential of political parties in making this discussion accessible to non-specialist citizens. ${ }^{46}$ While deliberative bodies composed of lay citizens generally include an intensive learning phase, this strategy is not available to the public at large. ${ }^{47}$ Instead, political parties can help to structure the public debate around a limited number of identifiable players and positions, giving visibility to the entire process and making it understandable. ${ }^{48}$ In addition, the involvement of politicians who have actual experience governing under the existing constitutional structure is an invaluable source of expertise

43 Stefan Rummens, 'Legitimacy Without Visibility? On the Role of Minipublics in the Democratic System,' in Constitutional Deliberative Democracy in Europe, ed. Min Reuchamps and Jane Suiter (Colchester: ECPCR Press, 2016).

44 See, e.g., John Parkinson, Deliberating in the Real World (Oxford: Oxford University Press, 2006), 33.

45 Parkinson, Deliberating in the Real World, 33.

46 Ian Budge, The New Challenge of Direct Democracy (Cambridge: Polity Press, 1996), 38-43; James Johnson, 'Political Parties and Deliberative Democracy,' in Handbook of Party Politics, ed. Richard S. Katz and William J. Krotty (London: Sage Publications, 2006), 48; Stefan Rummens, 'Staging Deliberation: The Role of Representative Institutions in the Deliberative Democratic Process,' The Journal of Political Philosophy 20 (2012): 31; Thomas Christiano, The Rule of the Many: Fundamental Issues in Democratic Theory (Boulder, CO: Westview Press, 1996), 222-24, 244-48.

47 John Parkinson has found that media coverage of deliberative mini-publics largely fails to convey the learning experience of the actual participants to the wider public (John Parkinson, 'Rickety Bridges: Using the Media in Deliberative Democracy,' British Journal of Political Science 36 [2006]: 183).

48 Rummens, 'Staging Deliberation,' 31. 
when designing the new constitution. ${ }^{49}$ More pragmatically, the support of political parties will often be necessary in order to ratify the proposed constitutional reform. Either directly by supporting it in parliament - if parliament is tasked with ratifying the constitution - or indirectly by providing organizational and financial support during the referendum campaign. ${ }^{50}$

All of this suggests that the goal of democratic constitution-making should not be to do away with representative institutions altogether, but rather to adapt and complement them in order to make the constitution-making process more open and accessible for citizens, as well as shift the focus away from short-term political interests and towards the long-term interests of the state. In short, to make 'entrance points for the public voice. ${ }^{51}$

\section{Lessons from abroad}

\subsection{Iceland}

\section{a Context}

The constitution-making process that was set up in Iceland in 2012 was a direct consequence of the global financial crisis of 2008 and the protests known as the 'Pots and Pans revolution' that followed. A new constitution was seen by protestors as an essential step to recover from the crisis, by laying down the values of the 'new Iceland. ${ }^{52}$ However, the widespread distrust towards the political class (which was deemed responsible for the crash of the country) led to the demand that the new constitution would be drafted in a participatory process. ${ }^{53}$

\section{b Process}

The drafting of the new constitution was initiated with the organization of a 'National Gathering' consisting of 950 quasi-randomly selected citizens who convened for one day to discuss in small groups what values should be reflected in the new constitution. ${ }^{54}$ The results of this gathering were then aggregated in eight different themes. ${ }^{55}$ Although most participants evaluated the National

49 Ethan J. Leib and Christopher S. Elmendorf, 'Why Party Democrats Need Popular Democracy and Popular Democrats Need Parties,' California Law Review 69 (2012): 111.

50 Leib and Elmendorf, 'Why Party Democrats Need Popular Democracy,' 112.

51 James Fishkin, 'Deliberation by the People Themselves: Entry Points for the Public Voice,' Election Law Journal 12 (2013): 503-7.

52 Paul Blokker, 'Grassroots Constitutional Politics in Iceland,' SSRN Working Paper (2012): 3, accessed October 4, 2015, http://ssrn.com/abstract=1990463.

53 Landemore, 'Inclusive Constitution-Making,' 7; Bjarki Valtysson, 'Democracy in Disguise: The Use of Social Media in Reviewing the Icelandic Constitution,' Media, Culture, and Society 36 (2014): 53.

54 Baldvin Thor Bergsson and Paul Blokker, 'The Constitutional Experiment in Iceland,' SSRN Working Paper (2013): 5, accessed October 4, 2015, http://papers.ssrn.com/sol3/papers.cfm?abstract_ id=2320748; Landemore, 'Inclusive Constitution-Making,' 4; Blokker, 'Grassroots Constitutional Politics in Iceland,' 6. Landemore, 'Inclusive Constitution-Making,' 19. 
Gathering positively, ${ }^{56}$ it has still come under criticism for its short duration and aggregative rather than deliberative methodology. ${ }^{57}$

The results of the National Gathering, along with the advice of various experts, were incorporated in a report written by the 'Constitutional Committee.'58 This report served as the basis for the deliberations in the Constitutional Assembly, which was supposed to consist out of 25 directly elected individuals. ${ }^{59}$ Strikingly, one of the eligibility requirements was that candidates could not be politicians in office. ${ }^{60}$

Because professional politicians were excluded from the Assembly, the election could not be based around existing political parties. Instead, the electorate could vote for 522 self-enlisted candidates, and select 25 out of them by means of a proportional electoral system. The turnout for these elections, however, was very low (30\%), precisely because political parties showed only little interest in the elections. ${ }^{61}$ As a result, the elections were insufficiently covered by the media. ${ }^{62}$ This shows the difficulty of realizing mass participation without the organizational support of political parties. This low turnout damaged the legitimacy of the Assembly from the start and provided arguments to politicians - who were often sceptical of the entire citizen-led process - to disregard the draft that would eventually be proposed. ${ }^{63}$

The legitimacy of the Assembly was further damaged when the Icelandic Supreme Court invalidated the results of the election due to irregularities in the electoral process. After much debate, the Icelandic parliament decided to politically appoint the 25 elected individuals to a 'Constitutional Council,' which was to replace the Constitutional Assembly. ${ }^{64}$ Despite a rocky start, it is the open and transparent way of working by the Constitutional Council that is widely seen as the most revolutionary aspect of the Icelandic process. ${ }^{65}$ The Constitutional Council invited the public to get involved and to give suggestions through the

$5690 \%$ of participants believed the National Gathering had gone well (Susan Burgess and Cristine Keating, 'Occupy the Social Contract! Participatory Democracy and Iceland's Crowd-Sourced Constitution,' New Political Science 35 [2013]: 425).

57 Bergsson and Blokker, 'The Constitutional Experiment in Iceland,' 5; Landemore, 'Inclusive Constitution-Making,' 18-19; Blokker, 'Grassroots Constitutional Politics in Iceland,' 6.

58 Landemore, 'Inclusive Constitution-Making,' 8.

59 Landemore, 'Inclusive Constitution-Making,' 4.

60 Bergsson and Blokker, 'The Constitutional Experiment in Iceland,' 6; Blokker, 'Grassroots Constitutional Politics in Iceland,' 7.

61 Thorvaldur Gylfason, 'Constitution on Ice' (2015): 5, accessed September 13, 2016, https:// notendur.hi.is/gylfason/Constitution\%20on\%20Ice\%207.pdf.

62 Landemore,'Inclusive Constitution-Making: The Icelandic Experiment,' 21.

63 Bergsson and Blokker, 'The Constitutional Experiment in Iceland,' 6; Blokker, 'Grassroots Constitutional Politics in Iceland,' 7.

64 Landemore, 'Inclusive Constitution-Making,' 4.

65 Landemore, 'Inclusive Constitution-Making,' 9; Tushnet, 'New Institutional Mechanisms,' 11. 
Council's website and through social media. These suggestions could then be commented on by others. ${ }^{66}$

However, an analysis of these comments by Valtysson has shown that the opportunities for real deliberation through the use of social media might be rather limited. ${ }^{67}$ Very often the actual sender of the request remained absent from the discussion, or the discussion was ended by a statement by one of the Council's members that 'A similar proposition was put forward in the Council, but it was not accepted,' without providing further reasons. ${ }^{68}$ On the other hand, there were also cases where the members of the Council actively engaged with the public, discussing the suggestions in more depth or providing substantive explanations as to why a certain point was not included in the draft. ${ }^{69}$ This seems to point to a general weakness in the design, namely that the 'feedback given (...) to individual suggestions (...) was irregular, informal and limited, probably because the possibility of feedback to the public wasn't properly institutionalized and funded. ${ }^{70}$

The Constitutional Council also regularly published the draft they were working on. These drafts were open to critique and suggestions from the public. According to Landemore, this incremental way of working - although not envisioned from the start of the process - created something of a 'feedback loop.' 71 Valtysson's analysis seems to suggest that this feedback loop was more successful in generating direct communication between the Council and the public, because it was easier for the public to respond to concrete suggestions. ${ }^{72}$

Nevertheless, it should be noted that the actual involvement of the public was still rather limited. All in all, only 3600 comments have been made by the public. ${ }^{73}$ This low figure has been attributed to the fact that the workings of the Constitutional Council were not sufficiently advertised, both because it was not widely covered by the media and because the Constitutional Council itself did not have funding to advertise the possibility of submitting comments. ${ }^{74}$

Also, despite the general transparency and openness towards public involvement that characterized the entire process, it was still in the Council that the actual decision-making took place. In addition, the Council's deliberations were not always open to the public, so that some secrecy was still involved. ${ }^{75}$ This, however, should not necessarily be seen as a weakness of the process. Some degree of Era: Lessons from Iceland and Ireland,' B.C. Int'l \& Comp. L. Rev. 251 (2015): 262.

68 Valtysson, 'Democracy in Disguise,' 65.

69 Valtysson, 'Democracy in Disguise,' 65.

70 Landemore, 'Inclusive Constitution-Making,' 17.

71 Landemore, 'Inclusive Constitution-Making,' 9.

72 Valtysson, 'Democracy in Disguise,' 65.

73 Landemore, 'Inclusive Constitution-Making,' 17; Suteu, 'Constitutional Conventions in the Digital Era,' 262.

74 Landemore, 'Inclusive Constitution-Making,' 17

75 Landemore, 'Inclusive Constitution-Making,' 15. 
secrecy - or perhaps better, 'privacy' - might in fact be helpful to deliberation. ${ }^{76}$ Since the contents of the Council's discussions were eventually disclosed and open to debate by the public at large, this approach of limited and temporary secrecy - or 'lag-time transparency' as Landemore calls it - was probably beneficial to the internal deliberation within the Council, without fundamentally harming the participatory aspects of the entire process. ${ }^{77}$

Eventually the Constitutional Council agreed on a final text which was adopted by consensus. Although decision-making through consensus was not a formal requirement, the council members took it upon themselves to present a 'united vision of the Icelandic people' to parliament, ${ }^{78}$ which still had to formally adopt the constitution. ${ }^{79}$

\section{c Outcome}

The Council's proposal was sent to parliament, along with the recommendation to subject the draft to a national advisory referendum. ${ }^{80}$ The referendum took place on October 20, 2012 and the draft constitution secured a very broad approval ( $2 / 3$ of the votes), despite the fact that - again - little effort was made by political parties to explain the draft to voters. ${ }^{81}$ The overwhelming support for the draft has therefore been attributed not so much to its content, which was quite progressive, ${ }^{82}$ but mostly to the fact that people wanted to voice their support for the open drafting process. ${ }^{83}$

After the referendum, the draft returned to parliament for a first vote. Despite generally welcoming the results of the referendum, parliament was divided on the draft constitution. ${ }^{84}$ Acceptance of the draft constitution by parliament was made

See, e.g., Amy Gutmann and Dennis Thompson, Democracy and Disagreement: Why Moral Disagreement Can Not Be Avoided in Politics and What Can Be Done about It (Cambridge, MA: Harvard University Press, 1996); Elster, 'Forces and Mechanisms,' 364.

77 Landemore, 'Inclusive Constitution-Making,' 20.

78 Suteu, 'Constitutional Conventions in the Digital Era,' 261.

79 The procedure for revision of the 1944 Icelandic constitution requires (much like the Belgian constitution) that constitutional revisions are adopted by two successive parliaments with elections in between (Bergsson and Blokker, 'The Constitutional Experiment in Iceland,' 2; Thorvaldur Gylfason, 'From Collapse to Constitution,' CESIFO Working Paper, no. 3770 (2012): 28, last accessed October 10, 2015, www.CESifo-group.org/wp.

80 Bergsson and Blokker, ‘The Constitutional Experiment in Iceland,' 9.

81 Gylfason, 'Constitution on Ice,' 11.

82 The draft constitution was reviewed by a number of international experts, who praised both the innovative drafting process as well as the fact that the draft - if it becomes law - would be 'at the cutting edge of ensuring public participation in ongoing governance.' Zachary Elkins, Tom Ginsburg and James Melton, 'A Review of Iceland's Draft Constitution', The Comparative Constitutions Project (2012): 11, (last accessed July 2017, http://comparativeconstitutionsproject.org/wp -content/uploads/CCP-Iceland-Report.pdf?6c8912).

83 Landemore, 'Inclusive Constitution-Making,' 11.

84 Benediktsson, leader of the (conservative) Independence Party for example said that: '70 percent of voters had either stayed at home or voted against the draft from the Constitutional Council. Only 30 percent of the population has said yes to the first question' (Bergsson and Blokker, 'The Constitutional Experiment in Iceland,' 10). 
even more difficult because there was no general consensus on the consequences that were to be attributed to the referendum result. Whereas some politicians stressed that the outcome of the referendum meant that changes to the text should be only technical in nature, others took the advisory nature of the referendum as meaning that parliament was free to alter the text. ${ }^{85}$

After the elections, however, the project seems to have been abandoned. The reasons advanced for the failure of the draft vary, ${ }^{86}$ but it seems safe to argue that the process has alienated professional politics, which led to the lack of consensus on the draft constitution once it reached parliament. ${ }^{87}$

\subsection{South Africa}

\section{a Context}

A second example of a constitution-making process that was more open and inclusive than the traditional norm was the process that led to the South African constitution of 1996. Although in hindsight this process can be seen as a successful example of inclusive constitution-making, it should be noted that this was not at all clear from the outset. Each of the negotiating parties initially favoured a different means of constitution-making, based on the party's substantive goals and conception of South Africa's future constitutional identity. ${ }^{88}$

The first negotiating round, which was dubbed 'CODESA' (Conference for a Democratic South Africa), still very much reflected the preference of the sitting government - dominated by the National Party (NP) - for an elite-pact. However, after almost two years of negotiations, the process ground to a halt and eventually collapsed. ${ }^{89}$ In order to overcome the stalemate both parties agreed to a compromise. The African National Congress (ANC) accepted that the new government after the first democratic elections would be a government of national unity that would include members of all major political parties. This system of power sharing was to be entrenched in a provisional constitution adopted before the elections and drafted in a new round of negotiations, the so-called 'Multi Party Negotiations' (MPN). The NP, on its part, conceded that the final constitution would be adopted by the new, democratically elected, parliament and that the power-sharing mechanisms of the interim constitution could be left out of the final constitution. ${ }^{90}$

See for a list Landemore, 'Inclusive Constitution-Making,' 5.

Bergsson and Blokker, 'The Constitutional Experiment in Iceland,' 11; Tushnet, 'New Institutional Mechanisms,' 13; Suteu, 'Constitutional Conventions in the Digital Era,' 273.

Heinz Klug, 'Participating in the Design: Constitution-Making in South Africa,' Review of Constitutional Studies 18 (1996): 31.

89 Klug, 'Participating in the Design,' 39; Heinz Klug, 'South Africa's Experience in ConstitutionBuilding,' in Reconstituting the Constitution, ed. Caroline Morris, Caroline, Jonathan Boston and Petra Butler (Dordrecht: Springer, 2011), 58.

90 Klug, 'Participating in the Design,' 40 and 42; Klug, 'South Africa's Experience in ConstitutionBuilding,' 58. 
The South African constitution-making process thus consisted of two distinct phases. These were linked by the inclusion in the interim constitution of a number of constitutional principles that the final constitution had to abide by, which would be certified by the Constitutional Court. ${ }^{91}$

\section{$b$ Process}

During the first phase of the process, negotiations were still very much under control of the different parties, although citizens still participated to a certain degree in the form of mass action, demonstrations and petitions. ${ }^{92}$ Popular participation was thus informal and external to the negotiations themselves. ${ }^{93}$

While the secretive and closed nature of the negotiations in the MPN have been widely criticized as undemocratic, ${ }^{94}$ it could be argued that this was a necessary evil in order to create trust between the different negotiating parties and move the process forward. Especially the inclusion in the interim constitution of 34 constitutional principles was essential in this respect. By ensuring that some of their fundamental interests were guaranteed, the principles created the necessary confidence for the NP to accept that the final constitution would be drafted by a democratically elected constituent assembly, where the NP would undoubtedly be in the minority. The constitutional principles thus 'provided a zone of comfort for those who did not feel that their central concerns were likely to be adequately reflected in the democratic process. ${ }^{95}$

After the existing tricameral parliament had adopted the interim constitution, South Africa held its first democratic elections in 1994. The newly formed parliament - which consisted of a National Assembly and a Senate - formed the Constitutional Assembly in a joint sitting. ${ }^{96}$ Since none of the parties had achieved the required two thirds majority, ${ }^{97}$ negotiations and compromise would still be necessary. However, the experiences with the MPN had made it clear that the final constitution would have to be drafted in a more open process that included, rather than excluded, the public. ${ }^{98}$

The constitutional assembly began its work by creating six thematic subcommittees intended to establish the parameters of the discussion in their relevant areas. This was done through debate, but also through public hearings and workshops where NGO's and members of civil society participated on equal footing with poli-

91 Klug, 'Participating in the Design,' 50 and 51; Klug, 'South Africa's Experience in ConstitutionBuilding,' 69.

92 Klug, 'Participating in the Design,' 42.

93 Klug, 'Participating in the Design,' 43.

94 Siri Gloppen, South Africa: The Battle over the Constitution (Aldershot: Ashgate, 1997), 256.

95 Klug, 'South Africa's Experience in Constitution-Building,' 76.

96 Klug, 'South Africa's Experience in Constitution-Building,' 59.

97 See section 73(2) of the Interim Constitution.

98 Cristina Murray, 'A Constitutional Beginning: Making South Africa's Final Constitution,' UALR Law Review 23 (2000): 816. 
ticians, along with both local and international experts. ${ }^{99}$ The subcommittees thus involved the public in an indirect way, through a broad inclusion of civil society in their work.

The general public was also invited to participate through an extensive 'outreach program' that utilized different forms of mass media such as the press, radio and television. ${ }^{100}$ This information campaign had a double purpose, namely to educate the people on democracy and constitutionalism in an easy to understand language, and to ask the public's opinion. ${ }^{101}$ In total, the constitutional assembly received over two million submissions, which were copied, sorted and sent to the relevant committees. ${ }^{102}$ In addition, great effort was made to reach people living in rural areas by organizing local public hearings, often attended by members of the Constitutional Assembly themselves. ${ }^{103}$

In November 1995 the Constitutional Assembly produced a first working draft, which was widely published. ${ }^{104}$ Again, the Constitutional Assembly asked for submissions. The response in this second phase was much smaller, but the content of the submissions was more focused than before. This enabled the Constitutional Assembly to summarize submissions, organize them according to the relevant section, and present them as end-notes to the working draft. ${ }^{105}$

Some commentators were sceptical of the entire process and doubted whether the public's participation had any influence at all. Gloppen, however, has suggested to distinguish between the submissions from organized civil society and the submissions from the general public. While the former did influence the eventual outcome (for example on LGBTQ rights), the latter probably did not have the same impact due to their sheer number and rather un-focused nature. ${ }^{106}$ This is different, however, for the comments that were received in response to the published draft constitutions because these were better processed, which increased the chances of them being taken into account. ${ }^{107}$

Regardless of the actual influence the various submissions had on the final constitution, the outreach program had important indirect effects as well. First of all,

99 Murray, 'A Constitutional Beginning,' 823.

100 Murray, 'A Constitutional Beginning,' 817; Klug, 'South Africa's Experience in ConstitutionBuilding,' 70; Gloppen, South Africa, 258.

101 Murray, 'A Constitutional Beginning,' 816.

102 Murray, 'A Constitutional Beginning,' 817; Gloppen, South Africa, 257 and 260; Klug, 'South Africa's Experience in Constitution-Building,' 71.

103 According to Ebrahim, more than 200 members of the constitutional assembly were involved, and according to Gloppen in total over 1000 workshops were organized all over the country and around 95,000 people participated (Hassen Ebrahim, The Soul of a Nation: Constitution-Making in South Africa [Oxford University Press, 1998], 244; Gloppen, South Africa, 258).

104 Throughout the negotiations, new drafts were created and published, although these were not as widely circulated (Murray, 'A Constitutional Beginning,' 824).

105 Gloppen, South Africa, 261.

106 Gloppen, South Africa, 260.

107 Gloppen, South Africa, 261. 
the program was successful in creating a national dialogue on the constitution and in ensuring a general sense of ownership of the constitution. All of this increased the legitimacy of the final product. ${ }^{108}$ Secondly, it seems that the open and transparent character of the entire process had an important influence on the tone of the debate within the constitutional assembly itself, which was less partisan. ${ }^{109}$ Whereas the MPN was a textbook example of political bargaining, Ramophosa - the chairman of the constitutional assembly - continuously insisted that 'the Constitutional Assembly was no place for rhetorical speeches and political grandstanding. ${ }^{\text {"10 }}$ Thirdly, the publicity of the negotiations also made it more difficult to defend arguments that were clearly intended to protect individual interests rather than the general interest. ${ }^{111}$ The final constitution thus shows fewer signs of being a compromise when compared to the interim constitution. ${ }^{112}$

Although the negotiating process was initially very open, more and more closed meetings were organized as the Assembly faced its most controversial issues. Although initially very informal, these meetings became more formal later on, sometimes lasting several days. These meetings away from the press were essential in order to resolve contentious issues. As was mentioned before, this is not necessarily a bad thing as long as the eventual outcome of the secret meetings is made public and are open to debate. This was not always the case in the South African process, however. Especially as the final deadline drew nearer. Some of the most contentious issues - such as education, property, and labour rights were settled over the last days of the negotiations. ${ }^{113}$ As a result, they were never open to comment by the public.

\section{c Outcome}

In the end, despite the sometimes difficult negotiations, the Constitutional Assembly approved the final constitution with only two nays and nine abstentions. ${ }^{114}$ This was not the end of the process, however, since the constitution's compatibility with the constitutional principles still had to be certified by the Constitutional Court. The Constitutional Court first refused to certify the constitution, but eventually validated the constitution after it had been amended by the Constitutional Assembly. ${ }^{115}$ The constitution was finally signed into law by President Mandela on December 10, 1996. ${ }^{116}$

108 Gloppen, South Africa, 264 and 266.

109 Murray, 'A Constitutional Beginning,' 831.

110 Murray, 'A Constitutional Beginning,' 812.

111 For the importance of publicity, see Gutmann and Thompson, Democracy and Disagreement.

112112 Because of this, Klug categorized the process as a 'process of integration,' where negotiations and public contestation interacted and led the negotiating parties to embrace more sustainable alternatives (Klug, 'South Africa's Experience in Constitution-Building,' 61).

113 Murray, 'A Constitutional Beginning,' 812.

114 Murray, 'A Constitutional Beginning,' 832.

115 Ebrahim, The Soul of a Nation, 216.

116 Murray, 'A Constitutional Beginning,' 837. 


\subsection{Comparison and evaluation}

a A transparent and open drafting process is important

A first lesson that can be drawn from the processes discussed above, is that in these cases the drafters of the constitution themselves saw an open and transparent drafting process as important for the legitimacy of the resulting constitution. First, the transparency of the process and the broad involvement of the public helped to set the issue apart from ordinary politics and changed the tone of the debate. In Iceland, the Constitutional Council had taken it upon itself to adopt the draft constitution by consensus, even though there was no such formal requirement. In South Africa, the Constitutional Assembly - in the face of public scrutiny - was eager to distinguish its workings from the MPN. As a result, talk that was very partisan in nature was frowned upon.

Secondly, the public nature of the process was inductive to a more thorough reflection. This could be seen most clearly in Iceland, where the Constitutional Council's way of working - namely to gradually flesh out the constitution by publishing drafts, followed by a certain amount of time for comments by the public turned the drafting of the constitution into an iterative process, where issues could be revisited in response to evolving understandings. Although the Constitutional Assembly in South Africa did not proceed in the same structural way, the same effect was to a certain extent present. The interaction of negotiators with the public served as the necessary catalyst for an evolving understanding on both sides of the table.

Thirdly, in both processes transparency was seen as an essential condition for the final product to be considered legitimate. Both in Iceland and in South Africa, the decision to organize an open drafting process was made in response to a legitimacy crisis. In Iceland, the financial crisis of 2008 had resulted in an atmosphere of distrust towards the political class. In South Africa, the mass demonstrations during the MPN had made it clear to all parties that the Constitutional Assembly would have to function fundamentally differently and would have to include the public, rather than exclude it.

However, although the transparency of both processes can in general be evaluated positively, in both cases a certain degree of secrecy was also instrumental to the eventual success of the negotiations. Still, a distinction has to be made. While the deliberations of the Constitutional Council in Iceland were only temporarily secret since the outcome of their discussions was always open for comment by the public, this was not the case in South Africa during the later stages of the negotiations. In addition, it could be argued that, even though the Constitutional Council was generally very successful in ensuring the transparency of its work, it was less successful when it came to making its work visible to the wider public. This distinction between transparency and visibility has been made by Rummens, who argues that: 
'[F]or citizens to understand which decision has been made (...) it is not sufficient to check through the internet the minutes of some committee meeting somewhere. Only the visibility of the political stage (...) gives the wider public of citizens adequate access to what is at stake in the decision-making process. $^{117}$

This lack of visibility of the process in Iceland can for example be derived from the low number of comments the Constitutional Council received. As mentioned before, this was mostly due to the limited participation by political parties as well as the limited media coverage of the entire process, and the Council's lack of funds to compensate for this. The South African process, although less transparent, was much more successful in ensuring visibility. Thanks to the broad outreach program, the entire population was regularly informed about the content of the ongoing negotiations, and most importantly, this was done in an easy to understand language. This was not only helpful in soliciting comments from the public, it also served an important educational function, educating the population on issues such as democracy, constitutionalism and human rights.

\section{$b$ Citizens should have real possibility to influence the outcome of the process}

Although essential, transparency or visibility as such is still not sufficient. From a normative perspective, it is also required that citizens have the possibility to influence the outcome of the process, so that they can see themselves not only as subject to, but also as 'co-author' of the constitution. ${ }^{118}$ While both the constitution-making processes in Iceland and in South Africa were characterized by a willingness of negotiators to invite the views of the public, the question remains to what extent this actually influenced the outcome of the process.

It was especially this aspect which caused some commentators to criticize the South African process. These criticisms do have some merit to them. Comments sent by ordinary citizens probably had limited effect, although comments sent in response to the published draft were arguably better taken into account. At the same time, however, comments sent by organized civil society did have an important effect. Civil society also greatly influenced the work of the thematic subcommittees, which served as the basis for the actual drafting of the final constitution. In addition, the broad outreach program set up by the constitutional assembly was successful in generating a lively public discussion in the informal public sphere, a discussion the Constitutional Assembly was also attuned to.

In Iceland, the participation by ordinary citizens - as opposed to organized civil society - had much more profound effects. First of all, through their participation in the National Gathering, they created a framework that would guide the Constitutional Council. Secondly, the Constitutional Council itself consisted entirely out of ordinary citizens. Thirdly, thanks to the use of modern means of communication, citizens could discuss ideas amongst themselves and with members of the

117 Rummens, 'Staging Deliberation,' 32.

118 Zurn, 'Democratic Constitutional Change,' 3. 
Council. Lastly, all citizens were able to vote on the draft constitution in an advisory referendum. Professional politicians only entered the picture after the draft had already been finished.

\section{c But political elites should not be alienated}

Although the radical participatory nature of the drafting process in Iceland has been widely applauded, it could at the same time be seen as one of the reasons for its eventual failure. It seems that by excluding professional politics from the most part of the process, the draft failed to generate the necessary support in parliament for it to be passed into law.

In contrast, in South Africa political elites remained at the centre of the process. This proved crucial for its eventual success, because it generated the trust between the parties that was necessary to overcome disagreement. In Iceland, disagreement between the various political parties only surfaced after the Constitutional Council had already sent the draft to parliament. Yet, at that time it was already too late to completely renegotiate the draft.

Citizen participation should thus be balanced with elite negotiation. Whereas it could be said that the constitution-making process in South Africa did not go far enough in providing ordinary citizens with the opportunity to actually influence the outcome of the process, the constitution-making process in Iceland arguably went too far by excluding political elites, whose support was indispensable for its success.

However, we should not ignore the specific context of the Icelandic constitutionmaking process: namely a context of crisis and deep distrust towards the political elite. While some members of the Constitutional Council were willing to accommodate some of the major points of the political parties - such as on the topic of ownership of natural resources ${ }^{119}$ - this could have reduced the popular support for the new constitution during the referendum. ${ }^{120}$ Especially because the opposition of the parties to some of the proposed changes were widely seen as being based on short-term and self-interested reasons. ${ }^{121}$

Perhaps a better way to ensure the continuing support of political parties is to have a mixed negotiating body consisting of both professional politicians and ordinary citizens. ${ }^{122}$ On the one hand, the presence of politicians in the drafting

119 Gylvason, 'Constitution on Ice,' 9.

120 Tushnet, 'New Institutional Mechanisms,' 13.

121 Gylfason, 'Constitution on Ice,' 18.

122 Such an approach has been used in Australia in 1999 where elected politicians were complemented with representatives from civil society as well as a number of directly elected ordinary citizens (Stephen Tierney, Constitutional Referendums [Oxford: Oxford University Press, 2012], 196). More recently, a constitutional convention was convened in Ireland in 2012. The council was composed of both ordinary citizens chosen by lot and elected politicians. Interestingly, this use of constitutional conventions seems to be growing into a regular feature of Irish constitutionmaking, the government having approved the creation of a new constitutional convention to debate the issue of abortion. 
process ensures that their points of view are not excluded, making it more likely for parliament to support and ratify the constitution, yet it does so without granting a veto. On the other hand, the presence of ordinary citizens in the negotiating body transforms the constitution-making-process and sets it apart from the ordinary legislative process. Because these citizens are - in the words of Mark Tushnet - 'one-shotters,' who do not have to run for re-election and who therefore do not stand to gain or lose personally from the implementation of the new constitution, short-term or party-political interests are less likely to play a major role in their deliberations. ${ }^{123}$ If politicians wish to convince these citizens, they too will have to appeal to long-term interests. ${ }^{124}$

\section{d The setting of guiding principles is helpful to the drafting process}

Both in Iceland and South Africa, the process was initiated by the drafting of principles intended to guide the rest of the negotiations. In South Africa, these principles were the result of elite bargaining in the MPN. In Iceland, on the other hand, the principles were themselves the result of a broader participatory process. Although the National Gathering has been criticized because its workings could have been more deliberative, it nevertheless provided an opportunity for ordinary citizens to sit together and discuss what they expected from the new constitution. This provided the Constitutional Council with clear guidelines during its work.

While the constitutional principles in South Africa were the result of elite bargaining, it should be noted that the role they played was very different than in Iceland. Instead of a legitimating function, their most important function was to generate trust between the negotiating parties. In other divided societies, the same use could be made of constitutional principles as a stepping stone towards more democratic constitution-making.

\section{e The societal context should be taken into account when designing the process}

This previous point immediately leads to a different important lesson one can take away from comparing the two processes, namely that different societal contexts merit very different choices when designing the constitution-making process and the role attributed to citizens in this process.

The same can be seen in the different attitudes drafters in Iceland and South Africa took towards the referendum and other, more direct, means of citizen participation. In Iceland, the financial crash had eroded the trust citizens had towards their elected politicians. The desire to distinguish the drafting of the constitution from the old political culture explains why the members of the Constitutional Council were so eager to include the public as much as possible. In addition, it was felt that in order to be truly legitimate, the work of the Constitutional

123 Tushnet, 'New Institutional Mechanisms,' 12.

124 Regardless of whether these long-term interests are their actually held beliefs, simply having to frame their arguments this way already makes the debate more deliberative. Elster calls this the 'civilising force of hypocrisy' (Jon Elster, 'Deliberation and Constitution making,' in Deliberative Democracy, ed. Jon Elster [Cambridge: Cambridge University Press, 1998], 111). 
Council had to receive the formal support of the entire population through a referendum vote. If the debate preceding the vote is broadly inclusive and respectful, the referendum can indeed be a useful means to formally and symbolically close the debate and ratify the new constitution. ${ }^{125}$

However, some contexts might be more suited for this kind of inclusive and respectful debate than others. It was precisely the fear for a divisive referendum campaign that would exacerbate the tensions in South African society rather than help to overcome them, which led the members of the Constitutional Assembly to prefer more indirect means of citizen participation. ${ }^{126}$ Chambers has described this potential danger of referendums as pitting 'We the people who won' against 'We the people who lost.' According to her, the very prospect of a majority vote can push citizens - or more often, political elites - to approach the debate strategically, placing people on different sides of a campaign, rather than as participants in a common conversation. ${ }^{127}$ By avoiding a direct vote on the new constitution, while at the same time investing heavily in consulting and informing the broader public, the Constitutional Assembly emphasized voice over votes. ${ }^{128}$

This does not necessarily mean that referendums can play no legitimating role in divided societies. The symbolic value of ratifying the new constitution through a public vote should not be underestimated. ${ }^{129}$ But it does place additional requirements on the design of such a process. Tierney, in his case study on the 1998 referendum in Northern Ireland, argues convincingly that for a referendum to play a unifying and legitimating role in a divided society initial cross-community agreement must be secured on the very question of holding the referendum. ${ }^{130}$ Such a consensus does not necessarily exist at the beginning of the negotiations, but will often depend on the inclusiveness of the drafting process itself. An inclusive drafting process has the potential to generate the trust and mutual respect that is necessary to overcome divisiveness during the referendum campaign. While certain fringe groups will undoubtedly still attempt to polarize the debate, a broad consensus amongst the negotiating parties regarding the need for an inclusive process might be able to avoid this risk and ensure that the mainstream debate remains respectful. On the other hand, if the drafting process excludes important voices in society, the referendum - or other forms of public consultation for that matter - will fail as a legitimating instrument. Although it might provide a formal right to participate, many citizens will nonetheless feel that their perspectives

125 On the role of referendums in ratifying constitutions, see Tierney, Constitutional Referendums and Elkins, Ginsburg and Blount, 'The Citizen as Founder.'

126 Murray, 'A Constitutional Beginning,' 831.

127 Simone Chambers, 'Constitutional Referendums and Democratic Deliberation,' in Referendum Democracy: Citizens, Elites and Deliberation in Referendum Campaigns, ed. Matthew Mendelsohn and Andrew Parkin (Basingstoke: Palgrave Macmillan, 2001), 240-45.

128 Chambers, 'Constitutional Referendums and Democratic Deliberation,' 231.

129 See,e.g., Ackerman, who suggests that referendums should be used to amend the American constitution (Bruce Ackerman, We the People, Volume 2, Transformations (Cambridge, MA: Harvard University Press, 1998).

130 Tierney, 'Constitutional Referendums,' 281. 
have not been taken into account. ${ }^{131}$ These feelings of resentment towards the exclusive drafting process will then manifest themselves during the referendum campaign. ${ }^{132}$

\section{$f \quad$ The process should be clear from the outset}

As a more general note, it is important that the process is clear from the outset. ${ }^{133}$ It seems that in Iceland there was no predefined roadmap for the entire process. This can be seen first in the somewhat clumsy election of the Constitutional Assembly, with its low turnout and the invalidation of the election results. Secondly, there was no official funding to advertise the possibility of sending comments. In addition, there were also no means available to systematically process the comments that were received. Lastly, the role of the referendum - although, as indicated before, potentially a powerful tool to legitimize the constitution - was problematic, because the exact consequences of its outcome were unclear which made the debate in parliament more difficult.

In South Africa, on the other hand, the process was clearer from the outset. The involvement of the public in the drafting of the final constitution was envisaged from the beginning of the Constitutional Assembly's work, along with the necessity of funding to achieve this goal. This enabled the Constitutional Assembly to set up a broad and well executed outreach program, with particular care given to reaching rural areas. At the later stages of the process, the Constitutional Assembly also took care to process all the comments it received. Each comment was sorted thematically, summarized and added as an endnote to the draft. This use of funds to invite people to submit comments and to subsequently process these comments was largely lacking in Iceland.

\section{Prospects for the future in Belgium?}

What lessons can be drawn from these experiences for the Belgian context? Firstly, the holding of a referendum - which is not only considered unconstitutional in Belgium by most authors, but also undesirable due to the complex nature of the Belgian state - is not the only way citizens can be included in the

131 Young calls this 'external exclusion,' see Iris Marion Young, Inclusion and Democracy (Oxford: Oxford University Press, 2000), 52-55; Banks, 'Expanding Participation in Constitution Making,' 1058.

132 Tierney refers to the referendum in Canada on the Charlottetown Accords. While the compromise that would be voted on enjoyed the support -albeit not wholeheartedly - of all major political parties, it nonetheless failed to be ratified. Arguably, many Canadian citizens felt excluded from the process and when they were allowed to voice their displeasure during the referendum vote, they did so in massive numbers. The inverse was arguably true in Iceland, where the draft constitution received broad public support during the referendum. Even though the actual content of the new constitution was not widely known since there was little in the way of a public education campaign (in contrast with South Africa), the open and inclusive nature of the drafting process was a source of confidence and trust, which increased the public support for the new constitution (Tierney, 'Constitutional Referendums,' 247).

133 For the same concern, see Suteu, 'Constitutional Conventions in the Digital Era,' 272. 
drafting process. In Iceland, the idea to hold a referendum only came to the foreground once the Constitutional Council had already completed its work, and in South Africa a broad consensus in the Constitutional Assembly was deemed preferable over a potentially divisive referendum campaign. Still, in both cases citizens were included throughout the process and in different ways. In Belgium as well, we should think creatively on how to actively engage citizens in the process instead of holding onto a strict dichotomy between direct and representative democracy. The soliciting of comments and suggestions from the public during the negotiations could be a first step towards more open and democratic forms of constitution-making.

Secondly, the inclusion of citizens does not have to entail the exclusion of politicians. Indeed, both the Icelandic and South African experience have shown that the continued support of professional politicians is an important precondition for the success of the drafting process. It could, however, be possible to give the responsibility of drafting the new or amended constitution to a mixed body, consisting of both politicians and randomly selected citizens, so that the process is still more participatory than was the case in South Africa. Just as in Iceland, the formal adoption of the new constitution could be left to parliament.

Thirdly, the current practice of negotiating the entire agreement behind closed doors should be avoided. Instead, it would be preferable to adopt a more transparent way of working and to regularly disclose working drafts and information and to allow the public to respond and contribute. The Icelandic example in particular, with its successful feedback loop, can be an important inspiration in this regard. At the same time, it should not be forgotten that transparency as such is not sufficient, but that the process should also be visible. It should be widely covered by the mass media, complemented by an official outreach program.

Lastly, in Belgium - just as in South Africa - constitutional principles could help to make the transition from a purely elite-led to a more democratic process. At the same time, however, it would be advisable that these principles are not exclusively decided by political elites. Instead, it could be possible to combine the practice of South Africa and Iceland, so that a large forum of randomly selected citizens could make a first proposal, which would then serve as the basis for negotiations at the political level.

In any event, it has become clear that it is no longer sufficient to ask where the next state reform should lead to, but that it is more than time to start asking how to get there. 